\title{
STUDI ETNOBIOLOGI TENTANG PEMANFAATAN TUMBUHAN RURUHI (Syzygium polycephalum Merr.) DI KOTA KENDARI SULAWESI TENGGARA
}

\section{Studi Etnobiology About Utilization of Ruruhi Plants (Syzygium polycephalum Merr.) in Kendari City, Southeast Sulawesi}

\author{
Wa Ode Nanang Trisna Dewi ${ }^{1}$ dan Adi Karya ${ }^{2}$ \\ 1,2, Program Studi Biologi, Fakultas Matematika dan IImu Pengetahuan Alam, Universitas Halu Oleo \\ JI. HEA Mokodompit, Anduonohu, Kendari -Sulawesi Tenggara \\ ${ }^{1}$ Corresponding author e-mail: nanang.ode@gmail.com
}

\begin{abstract}
Abstrak
Etnobotani merupakan ilmu botani yang mempelajari tentang pemanfaatan tumbuh-tumbuhan dalam keperluan sehari-hari dan adat suku bangsa. Penelitian ini bertujuan untuk mengetahui persepsi masyarakat tentang pemanfaatan tumbuhan Ruruhi (Syzygium polycephalum Merr.) di Kota Kendari, Sulawesi Tenggara. Metode penelitian ini menggunakan Metode deskriptif (kualitatif) untuk memperoleh gambaran seutuhnya mengenai suatu hal menurut pandangan manusia yang diteliti. Metode pengambilan data dengan cara terjun langsung ke lapangan atau masyarakat Kota Kendari.Pengambilan data menggunakan teknik wawancara dan dokumentasi gambar. Hasil penelitian menunjukkan bahwa persepsi masyarakat tentang pemanfaatan tumbuhan Ruruhi sangat beragam, diantaranya adalah dijadikan sebagai bahan bangunan sebesar $(0,024 \%)$, kayu bakar sebesar $(0,061 \%)$, obat-obatan sebesar $(0,049 \%)$, bahan makanan $(0,35 \%)$, penghias kebun $(0,11 \%)$, penghasil buah $(0,39 \%)$ dan pewarna alami $(0,012 \%)$. Organ tumbuhan yang dimanfaatkan adalah batang berjumlah sembilan orang, daun berjumlah 30 orang, bunga berjumlah dua orang, akar berjumlah satu orang orang dan buah berjumlah 82 orang.
\end{abstract}

Kata kunci: Etnobotani, Tumbuhan Ruruhi (Syzygium polycephalum Merr.) dan Pemanfaatannya

\begin{abstract}
Ethnobotany is a botanical science that studies the use of plants in the daily needs and customs of ethnic groups. This study aims to determine the public perception about utilization of Ruruhi Plants (Syzygium polycephalum Merr.) in Kendari City, Southeast Sulawesi. This research uses descriptive method (qualitative) to obtain the full image of a matter according to the human perspective studied. Methods of data collection by way of going directly to the field or the people of Kendari City. Retrieving data using interview techniques and image documentation. The results showed that community perceptions about the use of Ruruhi plants were very diverse, including building materials $(0.024 \%)$, firewood $(0.061 \%)$, medicines $(0.049 \%)$, food ingredients $(0.35 \%)$, garden decoration $(0.11 \%)$, fruit producers $(0.39 \%)$ and natural dyes $(0.012 \%)$. Plant organs that are utilized are nine people in stem, 30 in leaves, two in flowers, one person in roots and 82 people.
\end{abstract}

Keywords: Ethnobotany, Ruruhi Plants (Syzygium polycephalum Merr.) and Utilization 


\section{PENDAHULUAN}

\section{Latar Belakang}

Indonesia tidak hanya kaya akan keanekaragaman hayati dan ekosistem, tetapi juga memiliki keanekaragaman suku atau etnik, budaya dan pengetahuan lokal yang unik, tersebar dari sabang sampai merauke. Sulawesi Tenggara adalah salah satu provinsi yang ada di Indonesia memiliki sumber daya alam yang cukup potensial, baik dari segi tumbuhan, hewan maupun kekayaan alam lainnya. Kekayaan pengetahuan tentang pemanfaatan tumbuhan lokal, tidak terlepas dari adanya beberapa etnis atau suku besar yang berdomisili di wilayah tersebut seperti suku tolaki, suku muna, suku buton dan suku bugis. Masyarakat dari keempat suku tersebut memiliki pengetahuan dan persepsi berbeda tentang pemanfaatan sumberdaya alam termasuk tumbuhan lokal. Namun seiring dengan perkembangan zaman perubahan budaya tradisional dan lingkungan sering terjadi pula. Modernisasi budaya dapat menyebabkan tergerusnya pengetahuan tradisional masyarakat. Demikian juga dengan budaya pemanfaatan tumbuhan lokal oleh masyarakat dimungkinkan dapat hilang (Muttaqin, dkk., 2016).
Salah satu wilayah dengan penduduk suku tolaki, muna, bugis dan buton yaitu Kota Kendari. Masyarakat di daerah tersebut kebanyakan memanfaatkan tumbuhan lokal sebagai bahan makanan, obat, maupun untuk digunakan pada acara-acara pernikahan atau aqikahan. Namun demikian masih ada beberapa masyarakat yang memanfaatkan tumbuhan invasif dalam pemenuhan kebutuhannya sehingga secara tidak langsung tumbuhan lokal menjadi berkurang. Hal ini dikarenakan kurangnya pengenalan dan pengetahuan mengenai pemanfaatan tumbuhan lokal. Salah satu jenis tumbuhan lokal yang memiliki banyak potensi namun minim informasi adalah Ruruhi (Syzygium polycephalum Merr.). Tumbuhan ini adalah salah satu jenis tumbuhan lokal yang tergolong dalam suku Myrtaceae yang melakukan pemencaran biji guna mempertahankan jenisnya dari kepunahan (Mudiana, 2015). Selain itu memiliki keunikan tersendiri dibandingkan dengan tumbuhan lain yaitu bunga dan buah muncul dari batang, kulit buah berwarna merah hingga keunguan.

$$
\text { Irnawati dkk., }
$$
menyatakan bahwa tumbuhan ruruhi memiliki antosianin yang berpotensi 
sebagai pewarna alami dan sebagai antioksidan. Saat ini penelitian tentang tumbuhan ruruhi belum terlalu banyak dilakukan sementara keberadaannya di alam masih sudah mulai berkurang. Oleh karena itu, peneliti tertarik untuk melakukan kajian tentang persepsi masyarakat tentang pemanfaatan tumbuhan Ruruhi di Kota Kendari Sulawesi Tenggara sebagai dasar pelestarian tumbuhan tradisional masyarakat Kota Kendari. Bertujuan untuk mengetahui persepsi masyarakat tentang pemanfaatan tumbuhan Ruruhi (Syzygium policephalum Merr.) di Kota Kendari Sulawesi Tenggara.

\section{TINJAUAN PUSTAKA}

Sulawesi merupakan salah satu pulau yang memiliki keanekaragaman hayati terbesar di Indonesia dan memiliki keunikan flora tersendiri apabila dibandingkan dengan keanekaragaman flora di bagian lainnya. Keunikan tersebut disebabkan karena kawasan ini merupakan daerah antara (intermediate) bertemunya flora dari dua daerah yang berbeda, yaitu flora yang terdapat di sebelah barat dan timur Sulawesi (Rahayu dan Ruqayah, 2007).

Kota Kendari merupakan bagian dari wilayah administrasi dari Provinsi Sulawesi Tenggara. Batas-batas administratif Kota Kendari adalah sebelah Barat berbatasan dengan Kecamatan Pohara, sebelah Timur berbatasan dengan Teluk Kendari, sebelah Utara berbatasan dengan Selat Wawonii dan sebelah Selatan berbatasan dengan Bandara Wolter Monginsidi. Kota Kendari ini memiliki kekhasan karena di kelilingi oleh hutan dan teluk kendari. Kota Kendari memiliki masyarakat yang heterogen. Suku Tolaki merupakan salah satu dari tiga etnis terbesar di Provinsi Sulawesi Tenggara, dua diantaranya adalah suku Muna, dan suku Buton. Karakteristik ketiga suku tersebut dapat dibedakan atau dikenali berdasarkan kondisi geografis tempat bermukimnya. Suku Tolaki mendiami daratan pulau Sulawesi bagian tenggara, sedangkan suku Muna bermukim dipulau Muna, dan suku Buton dipulau Buton. Perkembangan selanjutnya, terjadi perpindahan suku Muna ke kota Kendari (pada waktu itu disebut Kendari Caddi) dengan membentuk pemukiman di lereng pegunungan Nipa-nipa kawasan Gunung Jati, menempati lahan-lahan pemukiman suku Tolaki yang merupakan penduduk asli kota Kendari dan bekas lahan perkebunan pembibitan jati milik Belanda.Suku Tolaki yang tinggal di kota Kendari merupakan salah satu 
suku bangsa di Indonesia yang masih menggunakan cerita rakyat sebagai pedoman dalam menentukan pandangan hidupnya (Idaman, 2012).

Pada awalnya pemanfaatan suatu jenis tumbuhan disebabkan oleh adanya sistem pengetahuan lokal (indigenous knowledge) mengenai tumbuhan pada suatu kelompok masyarakat tradisional. Pengetahuan ini terbentuk sebagai hasil dari cobacoba (trialand error), serta perkembangan budayamanusia yang selanjutnya dapat menciptakan kearifan lokal pada kelompok masyarakat tersebut (Martin, 1995dalam Pitra, dkk., 2017). Pengetahuan tentang suatu kelompok masyarakat terhadap pemanfaatan tumbuhan yang didapat secara turun temurun, dikenal dengan etnobotani. Meskipun dalam perkembangan modern saat ini tuntutan mengenai apa yang ada di dalam kelompok masyarakat tersebut dan mengandung nilai persepsi, pengetahuan, etika, moral, aturan dan teknologi (Zumaidar, 2009).

Pada masyarakat tradisional, sistem pengetahuan tentang sumberdaya alam khususnya tentang keanekaragaman tumbuhan merupakan pengetahuan dasar yang sangat penting dalam kelangsungan hidupnya. Tingkat pengelolaan dan pemanfaatan keanekaragaman jenis tumbuhan pada setiap suku atau kelompok masyarakat akan berbeda satu dengan lainnya. Hal ini disebabkan oleh adanya perbedaan kebudayaan, adat istiadat dan lingkungan tempat tinggalnya (Rahayu dan Rugayah, 2007: 289-299).

Pengetahuan lokal merupakan konsep yang merujuk pada pengetahuan yang dimiliki oleh sekelompok orang yang hidup di wilayah tertentu untuk jangka waktu yang lama, (Sunayo dan Joshi, 2003). Etnobotani adalah suatu ilmu yang mempelajari hubungan timbal balik secara menyeluruh antara masyarakat lokal dengan lingkungannya meliputi sistem pengetahuan tentang tumbuhan.Studi tentang hubungan manusia dan tumbuhan atau tanaman adalah domain ethnobotani yang mempelajari peranan manusia dalam memahami hubungannya dengan lingkungantempat tinggalnya, baik di lingkungan masyarakat tradisional maupun masyarakat industri (Walujo, 2011:275-291). Pengetahuan masyarakat tentang pemanfaatan tumbuhan lokal sebagai tumbuhan obat hanya sebatas pemanfaatan untuk halhal tertentu misalnya tumbuhan temu lawak sebagai bahan penambah nafsu 
makan (Atmojo, 2018). dan buah Ruruhi berpotensi sebagai pewarna alami dan sebagai antioksidan (Irnawati, dkk., 2017).

Salah satu tumbuhan yang melalukan pemencaran biji untuk mempertahankan keberadaan jenisnya adalah jenis tumbuhan Ruruhi (Syzgium polycephalum Merr.). Jenis yang dikenal dengan nama daerah Tapaco ini sering dijumpai di kawasan Cagar Alam Lamadae dan kawasan hutan lindung Nanga-Nanga Papalia (Zulkarnain dan Bana, 2010). Jenis ini masuk dalam kelompok jambujambuan. Di Australia di jumpai di daerah Queesland pada ketinggian 900m dpl (Mudiana, 2005).

Buah Ruruhi

(Syzygium polycephalum Merr.) adalahbuah dari tanaman liar suku jambu-jambuan atau Myrtaceae. Kulit buah Ruruhi berwarna merah hingga ungu. Antosianin adalah pigmen yang masuk dalam kelas flavonoid yang berperan dalam munculnya warna merah, biru dan ungu pada banyak bunga dan buah (Lima, et al. 2011 dalam Irnawati, dkk., 2017).

\section{METODOLOGI PENELITIAN}

Waktu dan Tempat

Penelitian ini dilaksanakan pada

bulan September - Oktober 2018.
Bertempat di Kota Kendari Sulawesi Tenggara. Analisis data dilakukan di lapangan dan Laboratorium Ekologi dan Taksonomi Fakultas MIPA Universitas Halu Oleo.

\section{Metode Pengambilan Data}

Metode penelitian menggunakan metode deskriptif (kualitatif) dengan cara terjun langsung ke lapangan atau masyarakat Kota Kendari untuk pengambilan data. Penelitian kualitatif ini bertujuan memperoleh gambaran seutuhnya mengenai suatu hal menurut pandangan manusia yang diteliti. Penelitian kualitatif berhubungan dengan ide, persepsi, pendapat atau kepercayaan orang yang diteliti dan kesemuanya tidak dapat diukur dengan angka.

Cara pengumpulan data menggunakan teknik interview yaitu peneliti mengadakan wawancara langsung kepada para tokoh masyarakat adat, kepala suku, kepala desa, kepala kampung guna mengetahui hal-hal yang berkaitan erat dengan kegiatan yang akan dilaksanakan khususnya terkait pemanfaatan tumbuhan Ruruhi, kemudian mencatat persepsi masyarakat tradisional Kota Kendari terhadap tumbuhan Ruruhi dan teknik dokumentasi yaitu peneliti mengambil 
gambar langsung dan mencatat hal-hal yang diperlukan di tempat penelitian guna dibuat dokumen-dokumentasi dan sebagai bukti bahwasannya peneliti melakukan penelitian di tempat tersebut.

\section{Teknik Analisis Data}

Data dalam penelitian ini dianalisis dan ditabulasi menggunakan Software WPS Exell 2016, kemudian ditampilkan dalam bentuk gambar diagram batang untuk memudahkan dalam pembacaan dan penerjemahan makna.

\section{HASIL DAN PEMBAHSAN}

\section{Sumber Pengetahuan Masyarakat tentang Tumbuhan Ruruhi (Syzygium polycephalum Merr.)}

Tumbuhan Ruruhi (Syzygium polycephalum Merr.) merupakan salah satu tumbuhan berbunga yang tergolong dalam suku Myrtaceae kelompok jambu-jambuan dan melakukan pemencaran dengan biji. Buah dan bunga muncul dari batang dan bergerombol. Selain itu tumbuhan Ruruhi merupakan salah satu sumberdaya alam hayati yang banyak dijumpai tumbuh liar di hutan dan memiliki manfaat yang beranekaragam.
Morfologi tumbuhan Ruruhi ditunjukkan pada Gambar 1.

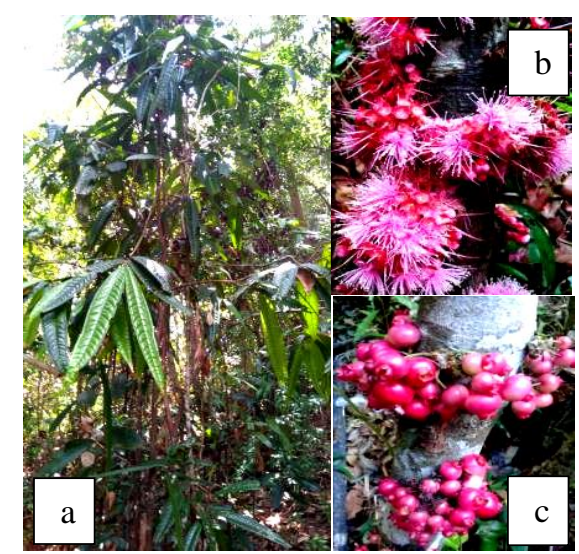

Gambar 1. Morfologi tumbuhan Ruruhi (Syzygium polycephalum Merr.). Ket: a. tumbuhan Ruruhi, b. bunga, c. Buah

Secara umum berdasarkan hasil wawancara dengan 82 responden (masyarakat), yang dilakukan di Kota Kendari ditemukan bahwa sebagian besar masyarakat mengenal dan mengetahui tumbuhan Ruruhi. Pengetahuan ini diperoleh secara turun-temurun dari nenek moyangnya dan pengetahuan yang diperoleh dari media cetak seperti buku, majalah dan lain-lain (Gambar 1 dan 2). Pengetahuan masyarakat terhadap tumbuhan Ruruhi ini dipengaruhi oleh interaksi masyarakat dengan tumbuhan Ruruhi tersebut, baik secara langsung maupun tidak langsung dalam lingkungannya. 


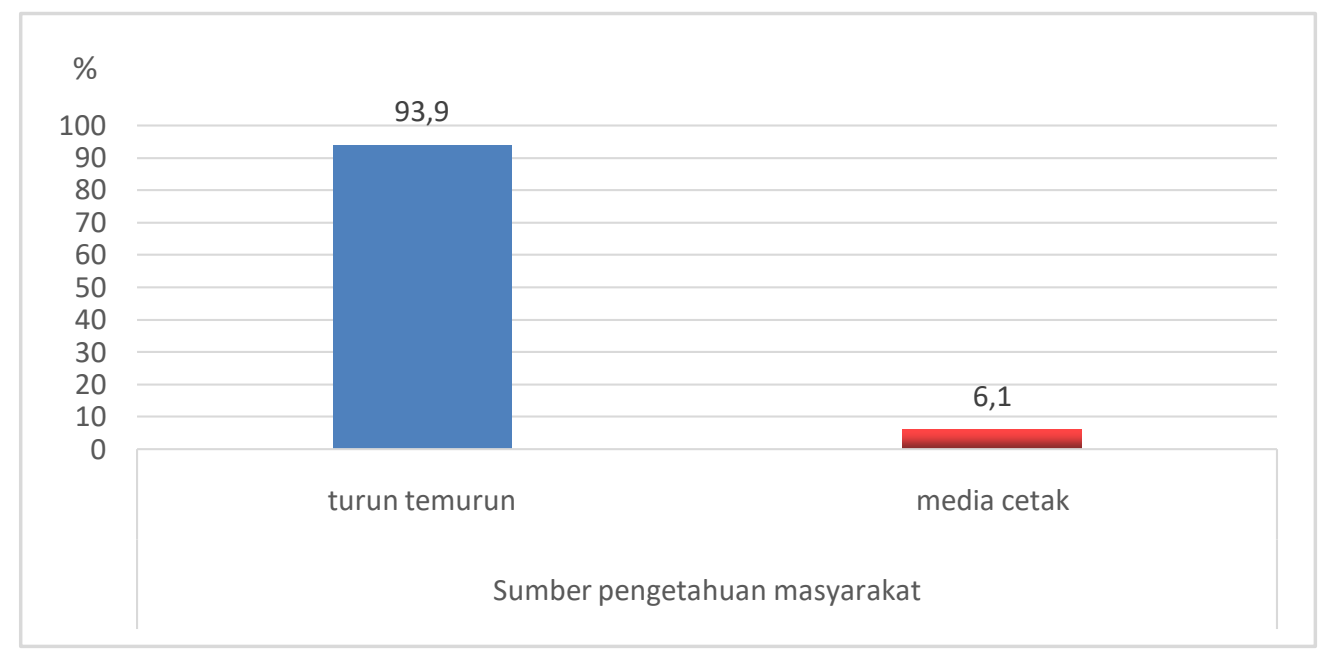

Gambar 2 . Sumber pengetahuan masyarakat

Berdasarkan Gambar 1 dan 2, menunjukkan bahwa tingkat pengetahuan masyarakat tentang tumbuhan Ruruhi (Syzygium polycephalum Merr.) bersumber dari pengetahuan yang diperoleh secara turun temurun sebesar $93,9 \%$, dengan nama lokal yaitu bebele, bhele-bhele, tapaco, waruruhi, lobe-lobe, dawet, ubol, jambu hutan, coping, bururuhi, anggur hutan dan anggur kecut dan pengetahuan yang bersumber dari media cetak sebesar 6,1\%. Adanya keragaman nama lokal pada tumbuhan Ruruhi disebabkan oleh adanya perbedaan pengetahuan tradisional masyarakat, yang dipengaruhi oleh adat istiadat, budaya dan suku yang menenpati wilayah tersebut. Pengetahuan atau kearifan tradisional masyarakat dalam pemanfaatan sumberdaya alam khususnya tumbuhandalam pangan, pengobatan dan yang lainnya merupakan kekayaan budaya yang perlu digali agar pengelolaan tradisional tersebut tidak punah. Sejalan dengan Rahayu, dkk., (2009), mengemukakan bahwa pengetahuan dan keterampilan masyarakat sangat berpengaruh terhadap pemanfaatan sumberdaya hayati. Pengetahuan lokal yang dimiliki masyarakat dalam memanfaatkan sumber daya hayati merupakan warisan yang diperoleh secara turun temurun dari nenek moyangnya. Sehingga secara tidak langsung masyarakat lokal, memiliki pengetahuan dan kemanpuan dalam mengenali, mencirikan, mengelompokkan serta memanfaatkan tumbuhan yang ada di sekitarnya.

\section{Persepsi Masyarakat tentang Pemanfaatan Tumbuhan Ruruhi}

Berdasarkan hasil wawancara terhadap responden (masyarakat), 
diketahui secara umum bahwa memanfaatkan tumbuhan Ruruhi tumbuhan Ruruhimemiliki berbagai sebagai bahan pangan (makanan), manfaat yaitu sebagai tumbuhan sebagai bahan obat, bahan bangunan penghasil buah, sebagai bahan obat, kayu bakar, penghias kebun, penghasil sebagai kayu bakar, bahan bangunan, buah dan sebagai pewarna alami makanan, penghias kebun dan (Gambar 3).

pewarna alami.Masyarakat yang



Gambar 3. Pemanfaatan tumbuhan Ruruhi oleh masyarakat

Dari Gambar 3 tersebut menunjukkan bahwa persentase pemanfaatan tumbuhan Ruruhi oleh masyarakat Kota Kendari dari besar sampai kecil secara berurutan adalah pemanfaaatan tumbuhan Ruruhi sebagai tumbuhan penghasil buah memiliki persentase paling besar yaitu sebesar $\quad 0,39 \%$, kemudian pemanfaatan tumbuhan Ruruhi sebagai bahan pangan (makanan) yaitu sebesar $0,35 \%$, penghias kebun sebesar $0,11 \%$, kayu bakar sebesar 0,061\%, bahan obat sebesar 0,049\%, bahan bangunan sebesar $0,024 \%$, dan sebagai pewarna alami memiliki persentase paling kecil yaitu sebesar $0,012 \%$. Hal ini terjadi karena setiap masyarakat Kota Kendari memiliki budaya, dan pengetahuan tradisional tentang pengelolaan dan pemanfaatan tumbuhan berbeda-beda khususnya tumbuhan Ruruhi. Tumbuhan Ruruhi banyak dimanfaatkan sebagai penghasil buah karena masyarakat lebih suka mengkonsumsi buah segar yang lansung dipetik dari pohonnya ketimbang harus membelinya di pasar. 
Sejalan dengan (Rosmanita dan Saharuddin, 2017), mengemukakan bahwa masing-masing wilayah memiliki pengetahuan tersendiri dalam pengelolaan dan pemanfaatan berbagai tumbuhan. Pemanfaatan tumbuhan Ruruhi sebagai penghasil buah oleh masyarakat Kota Kendari juga dilakukan oleh masyarakat di Pulau Wawoni, Sulawesi Tenggara dan masayarakat di Pulau Bali. Rahayu dan Rugayah (2007), menyatakan bahwa masyarakat di Pulau wawonii mengenal tumbuhan Ruruhi sebagai tumbuhan penghasil buah yang banyak dijumpai tumbuh di hutan dan menurut Sujarwo et al. (2014), menyatakan bahwa pemanfaatan tumbuhan Ruruhi oleh masyarakat Bali sebagian besar digunakan sebagai tumbuhan penghasil buah, sebagai tumbuhan obat, sebagai kayu bakar dan pewarna alami.

Organ tumbuhan Ruruhi yang dimanfaatkan oleh masyarakat Kota Kendari tidak hanya buah tetapi juga memanfaatkan daun, bunga, batang dan akar tumbuhan tersebut (Gambar 4). Berdasarkan hasil wawancara pada 82 responden ditemukan bahwa masyarakat yang memanfaatkan organ tumbuhan Ruruhi bagian buah, semuanya memanfaatkannya yaitu tercatat sebanyak 82 responden.
Selain itu selain buah masyarakat juga memanfaatkan organ lainnya seperti daun sebanyak 30 responden, batang sebanyak 9 responden, bunga sebanyak 2 responden dan akar satu responden. Masyarakat Kota Kendari memanfaatkan buah tumbuhan Ruruhi sebagai makanan anak-anak ataupun orang dewasa yang dijadikan makanan rujak dan dimanfaatkan sebagai obat penguat gigi. Organ daun tumbuhan Ruruhi digunakan sebagai lalapan, sebagai pengganti asam dan sebagai bahan obat. Batang tumbuhan Ruruhi umumnya digunakan sebagai kayu bakar, pagar dan sebagai tiang rumah serta bunga dan akar dimanfaatkan sebagai bahan obat luka dan pereda sakit perut. Organ buah dan daun ini, dalam pemanfaatannya dapat dikomsumsi langsung, dicuci, direbus sampai dihaluskan terlebih dahulu kemudian dikonsumsi. Perbedaan pemanfaatan sumber daya hayati seperti halnya tumbuhan Ruruhi oleh masyarakat lokal dipengaruhi oleh perbedaan pengetahuan dalam pengelolaan sumber daya hayati tersebut. Rahayu dan Rugayah (2007), menyatakan bahwa tingkat pengetahuan tentang pengelolaan dan pemanfaatan keanekaragaman jenis tumbuhan pada setiap suku atau kelompok masyarakat akan berbeda 
satu dengan lainnya. Hal ini disebabkan adanya perbedaan kebudayaan, adat istiadat dan kondisi lingkungan tempat tinggalnya.
Sehingga pemanfaatan sumberdaya hayati khususnya tumbuhan Ruruhi masing-masing responden berbedabeda sesuai dengan kebutuhannya.

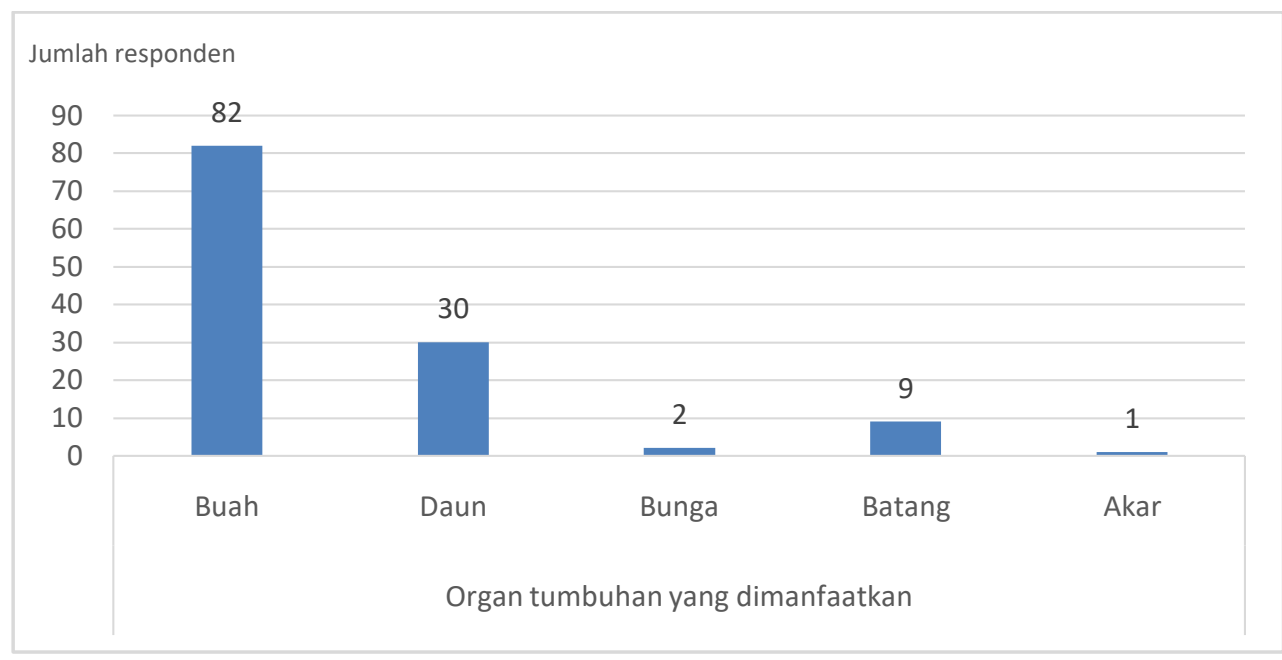

Gambar 4. Organ tumbuhan Ruruhi yang dimanfaatkan masyarakat

Dalam rangka pemanfaatan tumbuhan Ruruhi sebagai bahan pangan, obat, penghasil buah dan sebagainya juga harus memperhatikan aspek konservasinya. Hal ini dilakukan melalui pemanfaatan tumbuhan Ruruhi secara berkelanjutan, agar keberadaan tumbuhan Ruruhi tidak punah di alam. Dari hasil wawancara pada 82 responden (masyarakat) yang ada di Kota Kendari mengenai keberadaan tumbuhan Ruruhi di alam, diketahui bahwa sebanyak 54,88 \% responden mengatakan tumbuhan Ruruhi semakin sulit dijumpai, dan responden yang mengatakan bahwa tumbuhan Ruruhi masih mudah dijumpai di alam hanya sebanyak 45,12\%. Hal ini disebabkan oleh pengalihfungsian lahan, dari hutan menjadi lahan perkebunan, pemukiman dan pertambangan merupakan penyebab utama semakin sulitnya menjumpai tumbuhan Ruruhi di alam. Selain itu kelangkaan tumbuhan Ruruhi juga disebabkan oleh seringnya masyarakat menebang batang tumbuhan Ruruhi dijadikan sebagai pagar dan tiang rumah. Hal ini secara tidak langsung akan menurunkan jumlah populasi dari tumbuhan Ruruhi. Menurut Sunayo dan Joshi, 2003) mengemukakan bahwa kadang-kadang pengetahuan tradisionalyang sudah beradaptasi dengan baik dan efektif untuk mengamankan kehidupan masyarakat dalam lingkungan tertentu menjadi tidak sesuai lagi dibawah lingkungan yang sudah terdegradasi. 
Sehingga upaya konservasi perlu dilakukan untuk mencegah semakin menurunnya keberadaan tumbuhan Ruruhi di alam. Pelestarian terhadap tumbuhan Ruruhi tidak hanya dilakukan dengan cara melindungi habitat tumbuhan Ruruhi tetapi juga perlu adanya upaya budidaya tumbuhan Ruruhi, baik yang dilakukan oleh pemerintah maupun inisiatif langsung dari masyarakat.

Budidaya tumbuhan lokal merupakan bagian yang penting karena berdasarkan wawancara terhadap responden, umumnya responden mengenal tumbuhan ini sebagai tumbuhan liar dan banyak memberikan manfaat.Acharya dan Acharya (2010) menyatakan bahwa masyarakat lokal lebih cenderung mendukung dan berpartisipasi dalam inisiatif konservasi jika mereka mendapat manfaat langsung dari upaya tersebut. Upaya konservasi tumbuhan Ruruhi sejalan dengan pernyataan Sujarwo et al. (2014). Sujarwo et al. (2014) menyatakan bahwa tumbuhan Ruruhi merupakan salah satu spesies yang mulai langka keberadaannya di Pulau Bali. Perubahan penggunaan lahan diidentifikasi sebagai penyebab penurunan populasi tumbuhan Ruruhi. Lebih lanjut dijelaskan oleh Sujarwo et al. (2014) bahwa konservasi tanaman ini harus dilakukan baik secara in situ dan ex situ. Upaya ini diharapkan dapat menjaga kelestarian tumbuhan Ruruhi di alam karena eksploitasi secara terus menerus tanpa adanya upaya budidaya dapat mempercepat punahnya tumbuhan Ruruhi di alam.

\section{KESIMPULAN}

Kesimpulan dari penelitian ini adalah berdasarkan persepsi masyarakat tentang pemanfaatan tumbuhan Ruruhi (Syzygium polycephalum Merr.) di Kota Kendari dimanfaatkan sebagai tumbuhan penghasil buah (0,39\%), makanan $(0.35 \%)$, penghias kebun $(0,11 \%)$, obat $(0,049 \%)$, kayu bakar $(0,061 \%)$, bahan bangunan $(0,024 \%)$ dan sebagai pewarna alami (0,012\%). Organ tumbuhan yang dimanfaatkan masyarakat adalah secara umum memanfaatkan buahnya saja sebagian lagi memanfatkan semua organ tumbuhan ruruhi yaitu buah, daun, batang, bunga dan akar. Pemanfaatan organ tumbuhan ruruhi cukup banyak alternatif yang bisa dilakukan seperti buah dijadikan sebagai makan, obat dan rujak. Daun dijadikan obat, Ialapan dan pengganti asam. Batang dijadikan pagar, tiang rumah dan kayu bakar, bunga dan akar di jadikan obat. 


\section{DAFTAR PUSTAKA}

Acharya KP, Acharya, R. 2010. Eating from the wild: indigenous knowledge on wildedible plants in Parroha VDC of Rupandehi district, Central Nepal. Int $J$ Sci. 3:28-48

Atmojo, SE., 2018. Pengenalan Etnobotani Pemanfatan Tanaman sebagai Obat Kepada Masyarakat Desa Cabak Jiken Kabupaten Blora. Tanggal Akses 29 Juni 2018

Idaman, 2012. Islam dan Pergeseran Pandangan Hidup Orang Tolaki.Jurnal Al- Ulum, 12( 2): 267-302.

Irnawati, Zubaydah, S., Arifah. 2017. Anthoycanin Total and Antioxcidant Actifity Of Ruruhi (Syzygium polycephalum Merr.) Fruits. Jurnal Fharmacon, 6(3): 169-175

Mudiana, D., 2005. Pemencaran Syzygium cormiflorum (F. Muell.) B. Hyland. di Sekitar Pohon Induk dalam Cagar Alam Lamedae, Kolaka, SulawesiTenggara. Jurnal Biodiversitas, 6(2) :129-132

Muttaqin, AZ., Novianti, E., Partasasmita, R., Iskandar, J., 2016. Studi Etnobotani Pemanfaatan Jenis-Jenis Tumbuhan yang Digunakan sebagai Obat oleh Masyarakat Desa Pangandaran Kecamatan Pangandaran Kabupaten Pangandaran. Prosiding Seminar MIPA 2016. Jatinangon. Pada Tanggal 2728 Oktober 2016

Pitra, H., Haerullah, A. dan, Papuangan, N., 2017.Studi Pengetahuan Lokal Masyarakat Moya tentang Pemanfaatan Tumbuhan sebagai Obat Tradisional. Jurnal Saintifik.1(1): 45-49
Rahayu, M. dan Rugayah, 2007, Pengetahuan Tradisionaldan Pemanfaatan Tumbuhan Oleh Masyarakat Lokal Pulau Wawonii Sulawesi Tenggara. Berita Biologi.8(6) : 489-499

Rosmanita, I. dan Saharuddin. 2017. Hubungan Tingkat Pengetahuan Lokal Masyarakat Desa Ciherang dengan Tingkat Pengelolaan Tanaman Obat Keluarga. Jurnal Sains Komunikasi dan Pengembangan Masyarakat (JSKPM). (online). 1(3): 359378

Sujarwo, W., Arinasa, I. B. K. Caneva, G and. Guarrera. P. M., 2014. Traditional knowledge of wild and semi-wild edible plants used in Bali (Indonesia) to maintain biological and cultural diversity. Plant Biosystems. DOI:

10.1080/11263504.2014.9945 77

Sunaryo dan Joshi, L. 2003. Peranan Pengetahuan Ekologi Lokal dalam Sistem Agroforestri. Bahan Ajaran Agroforestri 7. Word Agroforestry Centre (ICRAF) Southeast Asia. Bogor, Indonesia.

Walujo, E.B. 2011. Sumbangan IImu Etnobotani dalam Memfasilitasi Hubungan Manusia dengan Tumbuhan dan Lingkungannya. Jurnal Biologi Indonesia. (online).7(2): 375-391. https://media.neliti.com/media/ publications/79020-IDsumbangan-ilmu-etnobotanidalam-memfasil.pdf. diakses 7 November 2018.

Zumaidar. 2009. Kajian Kearifan Lokal Euphorbiaceae sebagai Tumbuhan Obat oleh Masyarakat Aceh. Jurnal Agrista. Vol 13 (1): 43-48. 